\title{
Does default probability matter in Latin American Emerging markets?
}

\author{
Isabel Abinzano, Luis Muga and Rafael Santamaría \\ January, 2013
}

\begin{abstract}
:
We analyse the impact of default probability in four leading Latin American stock markets (Argentina, Brazil, Chile and Mexico). We find no positive default risk premium except in the case of Brazil, and in fact find a negative risk premium for Argentina and Mexico. The latter effect tends to fade when the analysis accounts for size and BTM market variables. Although we find no size effect in any of the markets considered, the BTM effect is very strong in all of them, and our results reveal a consistent relationship, analogous to that found in more developed markets, between default probability and the size and book-to-market variables.
\end{abstract}

Keywords: Default probability, size, book to market, emerging markets

JEL: G10, G14

\section{ACKNOWLEDGEMENTS}

The authors thank the editor and anonymous reviewers for their helpful comments and suggestions. This paper has received financial support from the Spanish Ministry of Science and Innovation (ECO2009-12819) and the Ministry of Economy and Competitiveness (ECO2012-35946-C02-01). Isabel Abinzano particularly acknowledges the financial support of the Andalusian Regional Government (P09-SEJ-4467). 


\section{Does default probability matter in Latin American Emerging}

\section{markets?}

\section{1.- Introduction.}

Relationships between firms' probability of default and their size and book-tomarket have been under debate in the financial literature for the last twenty years. Early studies of this issue, undertaken within the framework of the CAPM model, describe size and book-to-market effects as anomalies (see Sharpe, 1964 and Lintner, 1965). Thus, Banz (1981) documents the size effect, while Chan, Hamao and Lakonishok (1991) and Fama and French (1992), among others, report a bookto-market effect on stock returns. These studies show that investors can expect higher abnormal returns from firms with certain characteristics. In the case of small firms, this is due to a higher debt load, which increases their probability of default (Fama and French 1992). In firms with high book-to-market ratios, it is due partly to lower growth potential and partly to higher default risk (Fama and French 1992).

Based on this prior evidence, Fama and French (1993) add two additional factors to the CAPM by constructing two factor-mimicking portfolios to capture size (SMB) and book-to-market (HML) effects. In separate studies, Fama and French (1995 and 1998) report evidence of a default-risk effect on the returns to these mimicking portfolios.

Nevertheless, the Behavioural Finance approach argues that the observed value premium for stocks with extreme characteristics is too high to be explained by risk factors, and attributes more importance to aspects such as investor overreaction to certain types of announcement (Lakonishok et al. 1994). Arguing from a different perspective, Daniel and Titman (1997) claim that certain level of premiums, as the observed in the case of Book to Market, are not due to risk but to stock characteristics.

Several recent studies have related size and book-to-market effects to the level of default risk associated with the stocks. Using an approximation based on risk factors and another based on stock characteristics, Vassalou and Xing (2004), investigating the US market, show that a firm's default probability captures part of the size and book-to-market effects, but that the measure also incorporates information that is unconnected with such effects. Ferguson and Shockley (2003) reach similar conclusions, using an approximation based solely on risk factormimicking portfolios. The above-mentioned studies use different approaches for 
measuring firms' default probability. Ferguson and Shockley's (2003) use measures of default risk based on accounting data, such as Altman's Z-score or the leverage ratio. However, this approximation has several drawbacks. Accounting data reflect a firm's past performance and may offer little indication of its future prospects. Furthermore, since accounting-based models fail to consider stock volatility, firms with the same accounting ratios will present exactly the same degree of default probability. Vassalou and Xing's (2004) approach, in contrast, propose the use of a market-based default probability measure based on the Black-Scholes-Merton (BSM) option-pricing model, which derives a firm's default-risk level from the market price of its shares, thus overcoming some of the problems encountered when using accounting-based measures.

The literature also offers disparate findings as to the impact of stock characteristics and the momentum effect in emerging markets. Gupta and Modise (2012) shows that valuation ratios cannot predict stock returns in the South African Stock Exchange. Wang et al. (2012) finds no evidence of a momentum effect in the Taiwan Stock Exchange, while Muga and Santamaría (2007) find a weaker effect in Latin American emerging markets than in those of the developed countries. While some studies (Fama and French 1998, Rouwenhorst 1999, or Barry et al. 2002) have documented the presence of size and book-to-market effects in these markets, others (Claessens et al. 1995 or Serra 2003) have found, contrary to expectations, negative premiums for size and book-to-market variables for some countries. Nevertheless, the research has generally shown the value premium to be more robust than the size premium in emerging markets.

Although there is some degree of consensus as to the importance of size and book-to-market effects in this type of markets, there is less consensus as to whether these effects convey information about default risk. Indeed, Estrada and Serra (2005) show that Fama and French (1993) model, which incorporates these two stocks characteristics, do not yield satisfactory results for emerging markets. Our study, therefore, aims to provide an approximation of the role played by firms' default probability in Latin American emerging markets and its relationship with the size and book-to-market variables, using an approach based on stock characteristics.

In this respect, we offer several contributions to the literature. First, we test for the presence of a default risk premium in the four leading Latin American markets (Argentina, Brazil, Chile and Mexico), using a BSM-type measure for the 
estimation of default risk in order to circumvent problems arising from the use of accounting data for this purpose. We then test for an association between the default risk measure and the size and book-to-market variables in Latin American emerging markets, as Vassalou and Xing (2004) and Ferguson and Shockley (2003) have shown to be the case for the US market. Finally, we perform calculations to determine whether it is liquidity, a key variable that distinguishes developed from emerging markets, that drives these relationships.

To accomplish these objectives, the paper comprises eight sections. Section two presents the selected default risk measure. Section three describes the database for the study. Section four analyses the stock returns sorted by their level of default probability and size and book-to-market characteristics. Section five examines the relationship between default risk and firm size; and section six the link between default risk and the book-to-market effect. Section seven presents the robustness tests, where liquidity is included as a control variable. Section eight summarizes the main conclusions.

\section{2.- The default risk measure.}

Default risk, which can be defined as the uncertainty surrounding a firm's ability to service its debts and obligations, has been approximated in various ways throughout the literature. The most usual measures are those based on accounting data such as Altman's Z (1968) or Ohlson's O-score (1980), credit ratings, debt spreads and market-based measures, which use the BSM model.

However, as noted by Hillegeist et al. (2004), there are various reasons to question the effectiveness of default risk measures calculated using accounting data. One is that account statements are intended to measure past performance and may not tell us very much about a firm's future prospects. Furthermore, firms prepare accounting statements under the going concern principle, which assumes that the firm will not go bankrupt. Another major drawback of these measures is their failure to consider asset volatility, which leads them to conclude that firms with similar ratios will have exactly the same likelihood of going bankrupt. However, volatility is a crucial variable when attempting to predict default risk because it captures the probability of a firm's assets being insufficient to cover its liabilities. Ceteris paribus, the higher the volatility of a firm's asset value, the greater its default risk. 
An alternative to using the above-mentioned approximations of default risk is to construct a measure using firms' market share prices, as in Vassalou and Xing (2004), Byström et al. (2005), and Byström (2006), among others. These studies start from Merton's (1974) proposal, which is to consider the firm's own equity value as a European call option on its assets value and use the Black and Scholes (1973) formula to calculate it. Default risk is approximated by the following expression ${ }^{1}$ :

$$
P_{d e f, t}=N\left(-\frac{\ln \frac{V_{A, t}}{D_{t}}+\left(\mu_{t}-\frac{\sigma_{A, t}^{2}}{2}\right)(T-t)}{\sigma_{A, t} \sqrt{T-t}}\right)
$$

where $V_{A, t}$ is the value of the firm's assets at time $t, \mu_{t}$ is the expected immediate rate of return on $V_{A, t}, \sigma_{A, t}$ is asset return volatility, $D_{t}$ is the debt's face value, $T$ is the maturity period and $N(\cdot)$ is the cumulative probability of the Normal distribution. To find the values of $V_{A, t}$ and $\sigma_{A, t}$ we use an iterative process, similar to that used by Vassalou and Xing (2004), beginning with the market price of the firm's shares.

Thus, compared with accounting-based models, the BSM measure has the advantage that it not only takes into account each firm's past record, but also manages to include investors' expectations regarding future returns by considering its current share prices. In addition, it considers the firm's stock return volatility. Hillegeist et al. (2004) compare this measure, in this respect, to Altman's Z (1968) and Ohlson's O-Score (1980), finding BSM model to provide significantly more information regarding the firm's default risk than either of the other models, which leads them to recommend the use of the BSM measure to replace traditional accounting-based measures as a proxy for default probability. Furthermore, general databases, such as Thomson Financial, can provide scant data for these countries on some of the crucial variables needed to obtain default risk estimates. This fact could result in a major sample bias ${ }^{2}$.

\footnotetext{
${ }^{1}$ See Vassalou and Xing (2004) for further details.

2 Data on Earnings Before Interest and Taxes, for example, are available for only $1.7 \%$ of stocks in the Argentine stock market, $5.6 \%$ of stocks in the Brazilian market, $3.8 \%$ of stocks in the Chilean market and $5.5 \%$ of stocks in the Mexican market.
} 
Furthermore, compared with the credit rating, as a default proxy, the BSM measure has the advantage of no lag between variation in credit worthiness and its incorporation into the risk measure, given that, in the BSM measure market prices are discounting expected future cash flows. In addition, it is a firm-specific measure in that it provides a value for each firm based on its financial situation and its capitalization, which may differ from that obtained for another firm with the same credit rating. In this way it provides more finely-tuned rankings. Finally, requiring only a minimum amount of information, it provides a measurement value for every firm, not just those that are credit-rated.

The use of the BSM measure also overcomes some of the drawbacks associated with the use of credit spreads as a measure of default risk, such as the problem of multiple issues and the fact that the firm needs to have traded bonds before a default risk measure can be obtained. Note that it is usually easier to access a company's share price data than its debt return data.

As shown by Vassalou and Xing (2004), the aggregate BSM default index, defined as the simple average of all firms in a market, should signal periods of economic crisis, in the sense that they should be associated with higher aggregate market levels of default probability.

Figure 1 shows aggregate default rates by country. Thus, if the BSM index is a good default risk indicator, it should show some correlation with the periods of economic crisis that occurred in these countries during the sample period. It can be seen that this measure captures the main crises that took place in Latin America during the period analysed. In the case of the Argentine, the default rate reaches its peak with the first signs of economic distress towards the end of 2001, when extreme economic measures, including the notorious "corralito", introduced by the Minister of Economy, Domingo Carvallo, and vehemently protested by the public, triggered a major economic crisis. This spread to other Latin American countries in what was termed a "tango" effect, the strongest repercussions of which were felt in Brazil, Paraguay and Uruguay (which, together with the Argentine, make up MERCOSUR). Brazil's default risk rose between 1998 and 1999. Internal issues aside, the South East Asian financial crisis of 1997 and, especially, Russia's 1998 default on its debt may clearly have triggered the Brazilian financial crisis. The data for Chile show default beginning to rise in 1998 through the knock-on effect of the Asian Crisis of 1997, due to Chile's geographical proximity and economic ties with Asian countries. Lastly, it is possible to see the effect of the "tequila" crisis 
from 1994 onwards, particularly in Mexico, whose economy was thrown into frenzy, following devaluation of the peso. The situation spread to the whole of Latin America and its effects persisted until 1996.

\section{3.- The database.}

The data, taken from the Thomson Financial database, refer to all stock listed in four Latin American Emerging Markets: Argentina, Brazil, Chile, and Mexico between between November $1992^{3}$ and December 2007. In line with Ince and Porter (2006), we have screened and corrected the database. We have removed padded zero-return records at the end of the return time series for delisted stocks. We have also removed all nonlocal firms, all listings other than those on the primary exchange, and all listings with Type not equal to Equity. We include only those firms that checked YES in the "Primary quote" field. Banks, finance companies and insurance companies have been excluded from the analysis, because the peculiarities of their capital structure might skew the default risk data. We have also removed firms with missing data for some of the variables needed to calculate the selected default risk measure.

Finally, the availability of data on market value and short-term and long-term debt also had a noticeable impact on the sample, particularly during the first years of the database period. The average, maximum and minimum numbers of stocks available for the sample and for the different markets considered in the study are given in Table 1, which also shows the average values of the different variables used in the analysis (return, BTM, size and BSM). Cross-country disparity is evident, with the Brazilian market showing the highest average returns together with higher BTM ratios and higher BSM scores, while the Chilean market has the lowest returns together with a larger average firm size, lower BTM ratios and lower BSM scores.

Given the nature of the study, we use monthly data for the different variables with the exception of those related to the Amihud (2002) illiquidity measure since it requires daily data. Following Vassalou and Xing (2004), we avoid problems related to reporting delays by using debt data for the last three quarters of the current year and the first quarter of the past year. In line with other studies ${ }^{4}$, we

\footnotetext{
3 As noted in the previous section, BSM estimations require the use of past data to measure the volatility both of the firm's assets and its equity, which means that, although the study period starts in November 1992, the first BSM estimates are not obtained until January 1997.

${ }^{4}$ See, among others, Crouhy et al. (2000), Crosbie and Bohn (2003) and Vassalou and Xing (2004).
} 
calculate the book value of debt as the sum of short-term debt and $50 \%$ of long-term debt. As a proxy for the risk-free interest rate we have used the 30-day prime rate for Argentina, the Selic rate for Brazil, 90-day adjustable rate notes from Chile's Central Bank for Chile and 28-day CETES for Mexico.

\section{4.- Default risk, stock characteristics and stock returns.}

We begin our analysis of the relationship between default risk and stock returns by examining portfolios with different levels of default risk in order to detect potentially significant return differentials. We do this over a period running from January 1997 to December 2007 by sorting the stocks monthly into five portfolios using quintiles of the firms' default risk ranking. Finally, we calculate equally weighted returns of the five portfolios and the return differential between the highest and lowest default risk portfolios for each of the four countries under consideration.

The results, reported in Panel A of Table 2, differ across the markets considered. The Argentine market shows returns decreasing monotonically from the low default risk portfolio to the high BSM portfolio. In other words, in the Argentine stock market, shares with higher default risk show lower average returns over the study period. Specifically, the monthly return differential between the high and low portfolios is $-1.20 \%$ per month, the difference is significant at $10 \%$ using NeweyWest standard errors. In the Mexican stock market, although the return pattern is not monotonic, the return differential between the high and low portfolios has the same direction as in the Argentine market, that is, the returns of stocks with high BSM scores are lower, in this case by $-0.84 \%$ per month, which is significant at $5 \%$. In the Chilean stock market, however, there is no clear return pattern across the default risk portfolios, and the differential between the high and low BSM quintiles is not significant. Finally, the results for the Brazilian market contrast completely with those reported so far for the rest of the markets considered, in that they increase monotonically from the low BSM to the high BSM portfolio. The return differential between the high and low portfolios is $1.56 \%$ per month, the highest returns coming from the stocks showing the highest default risk.

Comparison of our results with those reported by Vassalou and Xing (2004) for the US stock market reveals that the only consistency, in terms of return patterns, between theirs and ours is for the Brazilian stock market, which is the only one 
where we find higher returns to be associated with higher default risk, approximated by the BSM measure.

Since Fama and French (1992), the research has suggested that a firm's default risk level could be linked in some way to its size and book-to-market characteristics. Thus, in the second part of our analysis, we use these two variables to characterize the BSM-based portfolios. Vassalou and Xing (2004) report that in their default risk portfolios higher default risk is associated with higher book-tomarket ratios and, overall, smaller firm size.

The results of this characterization for each market of interest are also given in Table 2 (Panel A). In line with the findings of Vassalou and Xing (2004), default probability appears to be linked both with size and book-to-market variables. Thus, in all the markets considered, the stocks located in the high default risk portfolio show higher book-to-market ratios and smaller firm size. This suggests that this is a reasonably accurate approximation of default risk, despite limitations deriving from the use of market variables in financial markets of this type. The observed relationship with returns cannot therefore be attributed to inaccurate estimation of default risk, but may derive from the characteristics of the assets traded on these markets.

These two variables do not present the same pattern, however. Firstly, the bookto-market variable behaves in exactly the same manner in all four markets, increasing monotonically except in the lowest default risk quintile. Secondly, size shows a less clear pattern than book-to-market, allowing us to report nothing beyond what has already been stated, namely, that the high default risk quintile is associated with smaller firm size in all four of the markets under consideration.

These relationships between the default risk portfolios and the size and book-tomarket variables could be the underlying factor for the observed variation in return patterns, given that there is no prior evidence of robust return patterns associated with these two variables in emerging markets, as already pointed out in the introduction to this paper.

\section{5.- The size effect.}

Vassalou and Xing (2004) have shown that default probability is more closely associated with size than with book-to-market in the US stock market. This motivates the second part of our analysis, which is to examine the relationship between BSM scores and firm size in Latin American markets. Nevertheless, a key 
prior to the analysis of these markets is that the listed firms do not adequately represent their respective economies. This, together with the fact that small firms are under-represented, may seriously affect analyses including this variable, particularly in view of the fact that, in developed markets, significant default risk premiums have been detected only within the small size portfolio.

\section{1.- The size effect and stock characteristics.}

In a Fama and French (1993) asset-pricing framework, the smaller the firm, the higher the risk, and, as a result, the higher the expected returns. In a Behavioural Finance framework, we would expect to find higher returns in the lowest size quintile, because small firm size can serve as a proxy for stocks that are hard to value or to arbitrage, or that have a more uncertain information environment (see Baker and Wurgler, 2006 or Jiang, Lee and Zhang, 2005).

The results for the size effect are shown in Panel B of Table 2. As with the default risk results, the return pattern for the size effect is also counter to expectations across the portfolios, in both, a Behavioral Finance or a Fama French model framework. Furthermore, in three of the markets considered, there is no significant difference in returns between large and small stocks. In the Chilean stock market, the average monthly return differential between large and small stocks is $0.48 \%$ per month, versus $-0.20 \%$ for the Argentine market, and $-0.63 \%$ for the Brazilian market, all these differences being non-significant according to the $t$ statistic, as already noted. In the Argentine and Brazilian markets, however, the small size portfolios yield the highest returns, as expected. Finally, we do find significant return differences between the large and small size portfolios in the Mexican stock market. Specifically, there is a difference of $0.97 \%$ between the average monthly returns from the largest and smallest size portfolios, although the sign is counter to expectations.

Again, as found for the portfolios based on the BSM measure, despite the divergence of the return patterns across the markets considered, a number of commonalities do emerge when the size portfolios are characterized by other variables. Thus, in all four stock markets, the book-to-market variable declines monotonically across the size portfolios from small to large, such that the smallest stocks present the highest average book-to-market ratios. In terms of the BSM measure, in the Chilean, Mexican and Brazilian markets, default probability is higher in the portfolios containing the smallest stocks, decreasing monotonically 
towards those containing the largest. The Argentine stock market, despite presenting a very similar overall pattern to the other three, differs in some ways, because, although the lowest average levels of default probability appear in the large size portfolio, the highest level does not appear in the small size portfolio.

The findings on firm size in relation to book-to-market ratios and default probability are consistent with those reported for developed markets, (see Vassalou and Xing 2004). That is, overall, small stocks show higher book-to-market ratios and higher default probability levels. Nevertheless, it is important to emphasize that portfolio return patterns vary across the different markets considered.

\section{2.- The size effect and default probability}

In light of the undoubted relationship that exists between default probability and firm size, the observed portfolio returns might be explained by a grouping of stocks sharing a specific characteristic. In this respect, Vassalou and Xing (2004) show that the default probability effect appears only in small stocks, and that the size effect is found only in stocks with high default probability.

In order to examine the effect of default probability across firm size groupings, we proceeded as follows. First, all the stocks in a given market were sorted into tertiles ${ }^{5}$ according to size, after which the stocks in each of the resulting groupings were again sorted into tertiles based on their default probability ranking, which is the variable of interest.

Panel A of Table 3 gives the returns of the default probability portfolios for the different firm-size groupings. In the Argentine stock market, no significant default probability effect is found in either large or small stocks. For the Chilean stock market, as occurred in the analysis of the portfolios based on the BSM measure, no significant return differentials appear among the different firm-size groupings. In the Mexican stock market, meanwhile, although the low default risk stocks present the highest returns, when they are re-sorted by size, the difference proves significant only for the middle firm size grouping, which shows an average monthly return differential of $0.91 \%$. Finally, the results for the Brazilian stock market also reveal a significant average monthly return differential of $1.10 \%$ and $1.16 \%$ between the high and low default probability portfolios in the large and small size groups, respectively, as indicated by the $\mathrm{t}$ statistic.

\footnotetext{
${ }^{5}$ In the formation of the two-way sorting portfolios, the first sorting was done by tertiles in the case of the Mexican and Chilean stock markets and by the median value in that of the Brazilian and Argentine stock markets, where the number of listed firms available was smaller.
} 
In summary, after controlling for size, the negative impact on returns of default probability fades in the Argentine stock market, while, in the Mexican market, its impact is found to be significant only in those firms located in the middle firm-size grouping. Meanwhile, the positive impact of default probability found in the Brazilian market holds for both the large and small size groupings.

In a similar manner, we examined the return patterns of the firm size portfolios across different levels of default probability. The results of this analysis, given in Panel B of Table 3, show that, across all four of the stock markets considered, size has no significant effect in any of the default probability groupings. Prior research nevertheless shows that the book-to-market effect is more robust than the size effect in emerging markets, as advanced in the introduction to this paper.

The results of this analysis allow us to conclude that there is a close association between firm size and default probability in the Latin American emerging markets. Firm size does not appear to have a significant impact on stock returns, however, and its effect is even less significant when considered in relation to default probability levels. As a final point, and as already noted, the under-representation of small firms in these markets may be a possible explanation for the results obtained.

\section{6.- The book-to-market effect.}

The second default risk-related variable traditionally reported in the literature is the book-to-market ratio. Fama and French (1992, 1995 and 1998) suggest that the higher returns associated with firms having higher book-to-market ratios might be related to default probability. Our analysis therefore proceeds by examining the relationships between default probability and book-to-market ratios in companies listed in the four Latin American stock markets under consideration.

\section{1.- The book-to-market effect and stock characteristics.}

We start, as in the analysis of the relationship between default risk and size, by forming portfolios based on BTM ratio quintiles for the four markets of interest and observing the stock returns and characteristics. In contrast to our findings for the analysis of size in relation to default risk, reported above, the book-to-market based portfolios show a uniform return pattern across the four stock markets considered, which is consistent with the traditional interpretation for both developed and 
emerging markets. That is, in all four markets, we find higher returns in the high BTM portfolios and lower returns in the low BTM portfolios.

The results are presented in Table 4, where it can be seen that, in the Brazilian stock market, the average monthly return differential between the high and low BTM portfolios is $2.44 \%$, versus $0.91 \%$ in the Mexican market, and $1.53 \%$ in the Chilean market. All these values are significant at $5 \%$ as indicated by the $t$ statistic. In the Argentine market, the average monthly return differential reaches $1.19 \%$ and it is significant at $10 \%$. With respect to the portfolio characteristics, as previous analyses suggest, the BTM portfolios correlate closely with both size and default risk. Thus, in all four of the markets considered, the high BTM portfolio contains the smallest firms. Furthermore, firm size decreases monotonically across the portfolios from low to high BTM stocks. Meanwhile, the portfolios containing the high BTM stocks also presents the highest default risk levels in all four stock markets. The default risk pattern is monotonically increasing from low to high BTM stocks in the Argentine and Chilean stock markets. In the Mexican and Brazilian markets, the pattern is not monotonic, but the high BTM portfolio presents lower levels of default risk.

The results displayed in this table reveal a strong impact of book-to-market on stock returns, which appears, at the same time, to be related to default risk and firm size.

\section{2.- The book-to-market effect and default probability.}

The return differentials among the book-to-market portfolios could be due to the relationships of the latter with other variables such as size or default probability. The differences may also be located in a specific group of stocks sharing a certain characteristic. We therefore repeated the analysis performed on the size-based portfolios, in order to examine the interaction between the book-to-market and default probability effects.

We start with an analysis of the effect of default probability on stock returns by book-to-market ratio levels. The results, which appear in Panel A of Table 5, reveal no default risk effect in the Chilean stock market. The Argentine stock market, likewise, shows no significant return differentials between high and low default risk stocks in any of the book-to-market groupings, although the analysis reported in Table 2 (Panel A) reveals an average monthly return differential of $-1.20 \%$ when no other variable is taken into consideration. 
The most striking of the results shown in Table 5 appear in the Mexican and Brazilian stock markets. The Mexican market continues to show differences in returns between the high and low default probability groupings. The specific monthly average return differentials are $-0.71 \%$ for the low BTM grouping, $-0.99 \%$ for the middle BTM grouping, and $-1.04 \%$ for the high BTM grouping. In other words, in the Mexican stock market, default risk still has a negative impact on at least one group of stocks when considered in relation to the size or book-to-market variables. Finally, the Brazilian stock market shows no significant effect of default risk on returns in either high or low BTM stocks, even though the previous analysis revealed an average monthly return differential of $1.56 \%$ among the default risk portfolios.

In summary, after taking into account the relationships with the book-to-market variable, while the default risk effect fades for all stock groupings in the Argentine, Chilean and Brazilian stock markets, it still has a significant impact in the Mexican stock market, albeit only in stocks located in the middle size grouping.

The second part of the study is an analysis of the effect of book-to-market on returns in the various default risk groupings. The results, shown in Panel B of Table 5, show that in this case, the significant return differentials among the bookto-market portfolios hold to some extent across all the stock markets considered. Thus, the Argentine stock market shows return differentials that are significant at $10 \%$ both in the high and low default risk groupings. In the Chilean and the Brazilian stock markets, a significant book-to-market effect is found in all default risk groupings. Finally, the Mexican stock market shows a significant book-tomarket effect in the low and middle default risk groupings. In other words, the book-to-market effect proves to be consistent across all countries when analysed in relation to BSM scores.

\section{3.- The book-to-market effect and size.}

Having observed an important book-to-market effect in all the markets considered, and having found that the returns of the book-to-market portfolios are significantly associated with firm size, we decided to run a similar analysis, this time constructing portfolios based on these two variables.

Table 6 shows the return patterns of the BTM portfolios by size groupings. As in the case of the analysis by default risk levels, all markets continue to show a significantly positive book-to-market effect in at least one size grouping. The effect 
is apparent in both the large and small size groupings for the Argentine market, in all size groupings for the Chilean market, in the middle and small size groupings for the Mexican market, and only in the small size groupings for the Brazilian market.

These results are consistent with those reported for developed markets in that the strongest book-to-market effect on returns occurs in small firms in all four of the markets considered in our study. Thus, in contrast to what was found for the size variable, the BTM variable responds as expected and does not therefore appear to be significantly affected by the data limitations of these markets.

\section{7.- Robustness Checks.}

The results obtained by means of stock portfolio analysis allow us to draw a number of conclusions. Firstly, default risk did not have a uniform impact on returns in all the markets considered during the sample period. Default premium is significant only in the Brazilian stock market and is in fact negative in the Argentine and Mexican markets. Secondly, as previous research on developed markets has reported, the observed default risk effect is associated with the size and book-to-market variables, and, except in the case of the Mexican market, the effect fades when either of these two variables is taken into consideration. Finally, the results illustrate the important role played by the book-to-market effect, which is present in all four of the markets considered, even when taking into consideration interactions with stock characteristics relating to default risk or firm size.

\section{1.- Fama-Macbeth regression on individual stock returns.}

The robustness of the above results has been checked using an alternative methodology to portfolio analysis. We have used Fama-Macbeth (1973) regressions in which stock returns for each market in a given month is explained in terms of firm size (Size), book-to-market ratios (BTM), level of default risk (DLI), and the interactions between these variables.

The estimated equations for each market considered were as follows:

$$
\begin{aligned}
& R_{i, t}=\alpha+\beta \cdot \text { Size }_{t-1}+u_{i, t} \\
& R_{i, t}=\alpha+\beta \cdot \text { BTM }_{t-1}+u_{i, t} \\
& R_{i, t}=\alpha+\beta \cdot D L I_{t-1}+u_{i, t} \\
& R_{i, t}=\alpha+\beta . \text { Size }_{t-1}+\gamma \cdot B T M_{t-1}+\lambda \cdot D L I_{t-1}+u_{i, t}
\end{aligned}
$$




$$
R_{i, t}=\alpha+\beta \cdot \text { Size }_{t-1}+\gamma \cdot B T M_{t-1}+\lambda \cdot D L I_{t-1}+\delta_{1} \cdot D L I_{t-1} \cdot \text { Size }_{t-1}+\delta_{2} \cdot D L I_{t-1} \cdot B T M_{t-1}+u_{i, t}
$$

The results, shown in Table 7 , are consistent in overall terms with those obtained from the portfolio analysis. In other words, the book-to-market ratio, whether considered in isolation or in conjunction with other variables, has explanatory power with respect to stock returns, in that higher BTM ratios are associated with higher stock returns. In the Brazilian and Argentine markets, moreover, the BTM ratio is the only variable that has predictive power when considered in conjunction with all other stock characteristics.

Default risk, as in the portfolio analysis, shows significant explanatory power with the expected sign only in the Brazilian stock market, and loses its significance when considered in conjunction with all the other variables.

These results confirm the findings obtained from the portfolio analysis with respect to the relationship between the book-to-market, size and default risk variables and the relative role of the book-to-market ratio in explaining stock returns in emerging markets. The default risk effect appears to be weak overall, fading altogether in the Brazilian market once the book-to-market effect is taken into account. This is consistent with findings for developed markets, where, according to several studies, size and book-to-market ratios might be serving as a proxy for firms' default risk.

\section{2.- Default probability and liquidity.}

Since one of the main distinguishing features between developed and emerging markets is the lower liquidity of the latter, this section incorporates liquidity into the analysis in order to check its impact on the relationship between default probability and stock returns in Latin American stock markets. Liquidity has a two-way causal relationship with default probability (Vassalou et al. 2006) and may explain future stock returns, since illiquid stocks should yield higher future returns than liquid stocks. Repeating the analysis using Amihud's (2002) ratio as a liquidity proxy, we find that, in contrast to the results for the variables examined in the previous analyses, in the case of liquidity, the impact of the probability of default on stock returns is concentrated in one specific group of stocks, the less liquid, regardless of the sign of the effect in the previous analyses ${ }^{6}$. This shows that the illiquidity of emerging markets has no role in determining the potential presence of a default risk premium. However the default risk effect, whatever its

\footnotetext{
${ }_{6}$ These results, not included in the paper to save space, are available from authors upon request.
} 
direction, is concentrated in less liquid stocks. Finally, in light of the negative relationship between size and liquidity, we acknowledge that these findings might be somewhat different if there were a greater presence of small firms in these markets.

\section{8.- Conclusions.}

This study has examined the probability of default in relation to a series of variables in the context of the Latin American emerging markets.

The initial finding is that default probability has a heterogeneous effect across the stock markets considered, although in all of them it is concentrated in less liquid stocks. Despite these differences, there are several common features. Specifically, the results indicate that there is an association between probability of default, size, book-to-market and liquidity. Thus, the stocks with the highest default probability are also the smallest, and have the lowest liquidity and the highest book-to-market ratios, just as occurs in more developed markets (Vassalou and Xing 2004).

Analysis of the impact of default probability on returns in different stock groupings shows that its effect tends to fade when the model accounts for size or book-to-market variables. This allows us to conclude that these two characteristics carry information relating to firms' probability of default, as is the case in more developed markets (Vassalou and Xing 2004 or Ferguson and Shockley 2003). These results hold for either portfolio analysis or Fama-MacBeth regressions.

The low representation of small firms in these markets might explain some of the results obtained and account for their heterogeneity, in as far as default risk premiums in the US market are found mainly in small firms, as shown by Vassalou and Xing (2004).

Finally, this study shows that book-to-market plays an important role in predicting stock returns in these markets and thus does more than simply provide information relating to firms' default risk. Further research is therefore required regarding the information content of this variable and the potential heterogeneity of its effects between developed and emerging markets.

\section{REFERENCES}

Altman, E. I. 1968. "Financial ratios, discriminant analysis and the prediction of corporate bankruptcy.” Journal of Finance 23, no. 4 (September): 589 - 609. 
Amihud, Y., 2002. "Illiquidity and stock returns: cross-section and time-series effects." Journal of Financial Markets 5, no.1 (January): $31-56$.

Banz, R. 1981. "The Relationship between Return and Market Value of Common Stocks.” Journal of Financial Economics 9, no. 1 (March): 3-18.

Baker, M. and Wurgler, J. 2006. "Investor Sentiment and the Cross-Section of Stock Returns.” Journal of Finance 61, no.4: 1645-1680.

Barry, C., Goldreyer, E. Lockwood, L. and Rodriguez, M. 2002. "Robustness of size and value effects in emerging equity markets, 1985 - 2000.” Emerging Markets Review 3, (March): 1 - 30 .

Black, F. and Scholes, M. 1973. "The pricing of options and corporate liabilities." Journal of Political Economy 81, no.3 (May-June): 637 - 654.

Byström, H. 2006. "Merton unraveled: A flexible way of modeling default risk." Journal of Alternative Investments 8, no.4 (Spring): 39 - 47.

Byström, H., Worasinchai, L. and Chongsithipol, S. 2005. "Default risk, systematic risk and Thai firms before, during and after the Asian crisis." Research in International Business and Finance 19, no.1 (March): 95 - 110.

Chan, L. K., Hamao, Y. and Lakonishok, J. 1991. "Fundamentals and stock returns in Japan.” Journal of Finance 46, no.5 (December): 1739 - 1764.

Claessens, S., Dasgupta, S, Glen, J. 1995. "Return Behavior In Emerging Stock Markets." The World Bank Economic Review, 9, No.1 (January): 131-151.

Crosbie, P. and Bohn, J. 2003. "Modeling default risk." Moody's KMV.

Crouhy, M., Galai, D. and Mark, R. 2000. "A comparative analysis of current credit risk models.” Journal of Banking and Finance 24, no.1-2: 59 - 117.

Daniel K. and Titman, S. 1997. "Evidence on the characteristics of cross sectional variation in stock returns.” Journal of Finance 52, no.1 (March): $1-33$.

Estrada J. and Serra P. 2005. "Risk and return in emerging markets: Family matters.” Journal of Multinational Financial Management 15, no.3 (July): 257-272. Fama, E. F. and French, K. R. 1992. "The cross-section of expected stock returns." Journal of Finance 47, no.2 (June): 427 - 465.

Fama, E.F, and French, K. R. 1993. "Common Risk Factors in the Returns of Stocks and Bonds.” Journal of Financial Economics 33, no. 1 (February): 3-56.

Fama, E. F. and French, K. R. 1995. "Size and Book to Market factors in earnings and returns." Journal of Finance 50, no.1 (March): 131 - 155.

Fama, E. F. and French, K. R. 1998. "Value versus growth: The international evidence." Journal of Finance 53, no.6 (December): 1975 - 1999. 
Fama, E.F. and Macbeth J. 1973. "Risk and return: some empirical tests.” Journal of Political Economy 81, no.3 (March): 607-636.

Ferguson, M. and Shockley R. 2003. "Equilibrium Anomalies." Journal of Finance 58, no.6 (December):2549-2580.

Gupta, R., and Modise, M.P. 2012. "Valuation Ratios and Stock Return Predictability in South Africa: Is It There?.” Emerging Markets Finance and Trade 48, no.1 (January-February): 70-82.

Hillegeist, S. A., Keating, E. K., Cram, D. P. and Lundstedt. K.G. 2004. "Assessing the Probability of Bankruptcy." Review of Accounting Studies 9, no.1: 5-34.

Ince, O. S., and Porter, R. B. 2006. "Individual equity return data from Thomson Datastream: Handle with care!." Journal of Financial Research, 29, no.4 (Winter): 463-479.

Jiang, G., Lee, Ch.M. and Zhang, Y. 2005. "Information uncertainty and expected returns.”, Review of Accounting Studies 10, no.2-3 (September): 185-221.

Lakonishok, J., Shleifer, A. and Vishny, R. W. 1994. "Contrarian investment, extrapolation and risk.” Journal of Finance 49, no.5 (December): 1541 - 1578.

Lintner, J. 1965. "The Valuation of Risk Assets and the Selection of Risky Investments in Stock Portfolios and Capital Budgets." Review of Economics and Statistics 47, no.1 (February): 13-37.

Merton, R. C. 1974. "On the pricing of corporate debt: The risk structure of interest rates." Journal of Finance 29, no.2 (May): 449 - 470.

Muga, L. and Santamaría, R. 2007. "The Momentum Effect in Latin American Emerging Markets." Emerging Markets Finance and Trade, 43, no.4 (July-August): $24-45$.

Newey, W.K. and West, K.D. 1987. "A simple, positive semi-definite, heteroskedasticity and autocorrelation consistent covariance matrix." Econometrica 55, no.3 (May): $703-708$.

Ohlson, J. 1980. "Financial ratios and the probabilistic prediction of bankruptcy." Journal of Accounting Research 18, no.1 (Spring): 109 - 131.

Rouwenhorst, R. 1999. "Local return factors and turnover in emerging stock markets." Journal of Finance, 54, no.4 (August): 1439 - 1464.

Serra, A. P. 2003. "The cross sectional determinants of returns: Evidence from emerging markets' stocks." Journal of Emerging Markets Finance 2, no.2: 123 162. 
Sharpe, W. 1964. "Capital Asset Prices: A Theory of Market Equilibrium under Conditions of Risk." Journal of Finance 19, no.3 (September): 425-442.

Vassalou, M. and Xing Y. 2004. "Default risk in equity returns." Journal of Finance 59, no.2 (April): 831 - 868.

Vassalou, M., Chen, J., and Zhou, L., "The Relation between Liquidity Risk and Default Risk in Equity Returns.” EFA 2006 Zurich Meetings. Available at SSRN: http://ssrn.com/abstract $=922622$.

Wang, C.P., Huang, H.H., and Huang C.H. 2012. "Momentum and Contrarian Profits Corresponding to the Coincident Economic Indicator on the Taiwan Stock Market.” Emerging Markets Finance and Trade, 48, Supplement 1: 29-40. 
FIGURE 1: Average value of the BSM measure aggregated by country

This figure shows the average value of the default measure given by the Black-Scholes-Merton model for Argentina, Brazil, Chile and Mexico, using the available data described in Section 3.
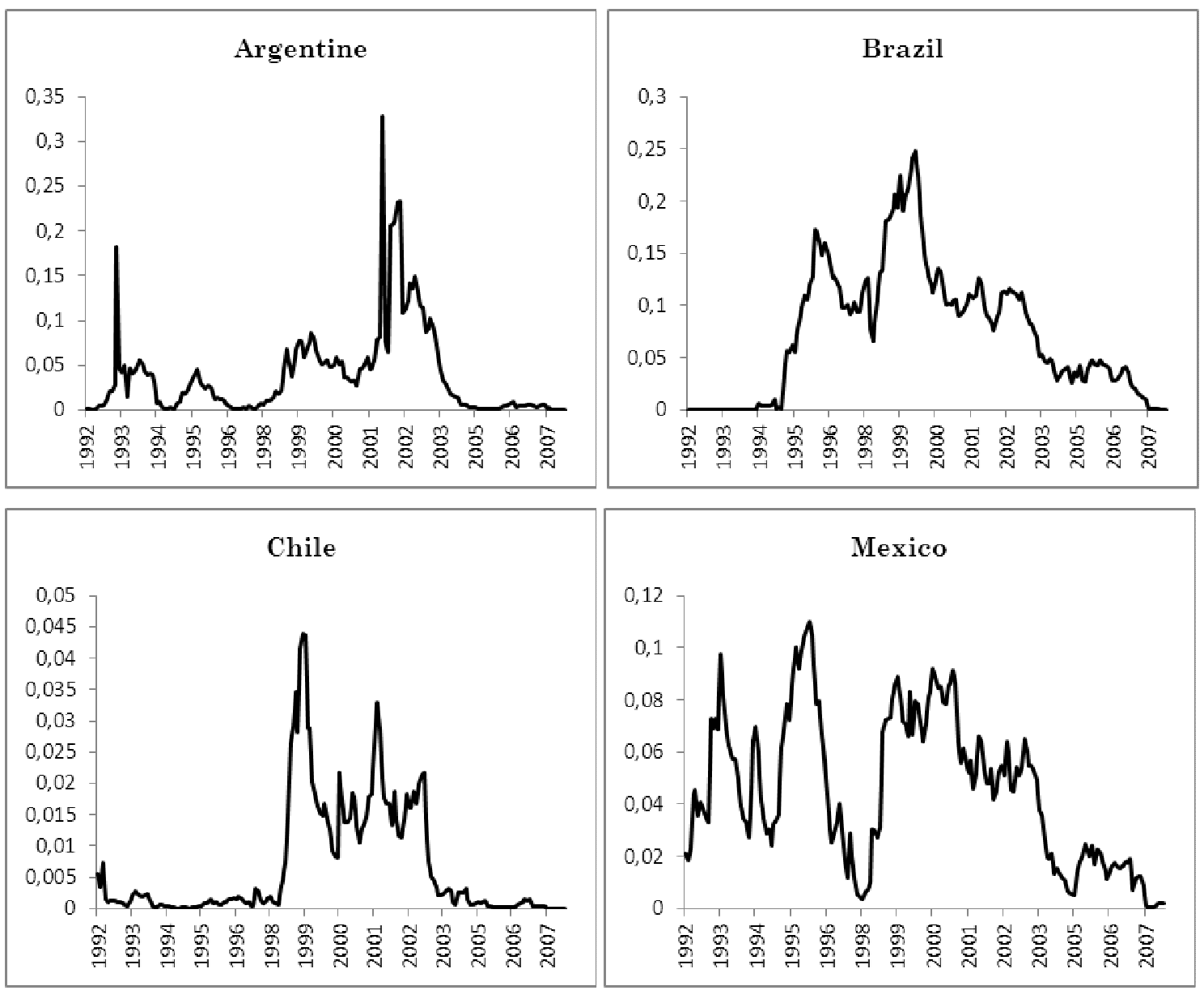


\section{TABLE 1: Descriptive statistics of the sample}

This table shows the average values of the stock characteristic variables used in the analysis: Return, Size, BTM and Default risk (BSM), and the average, maximum and minimum number of stocks.

\begin{tabular}{lccccccc}
\hline & Return & Size & BTM & BSM & Avg. & Min. & Max. \\
\hline Argentine & 0.00546 & 19.38 & 1.494 & 0.0420 & 48 & 31 & 62 \\
Brazil & 0.01456 & 20.74 & 2.337 & 0.0834 & 95 & 55 & 134 \\
Chile & 0.00281 & 25.35 & 1.086 & 0.0176 & 109 & 67 & 129 \\
Mexico & 0.00362 & 21.91 & 1.313 & 0.0472 & 89 & 62 & 107 \\
\hline
\end{tabular}


TABLE 2: Return and Characteristics of BSM and Size Portfolios

This table presents the average return, Size and BTM characteristics of the BSM portfolios (Panel A) and the average return, BSM and BTM characteristics of the Size portfolios (Panel B) in each of the markets considered for the period January 1997 - January 2007. * and \# denote return differentials (H-L, High minus Low, and B-S, Big minus Small) that are significant at the $5 \%$ and $10 \%$ levels, respectively, using the Newey-West (1987) standard errors.

\begin{tabular}{|c|c|c|c|c|c|c|c|}
\hline \multicolumn{8}{|c|}{ Panel A: BSM Portfolios } \\
\hline ARGENTINE & Low & 2 & 3 & 4 & High & H-L & \\
\hline Return & 0.0088 & 0.0027 & 0.0012 & 0.0015 & -0.0031 & -0.0120 & \# \\
\hline BTM & 1.3155 & 1.2603 & 1.3878 & 1.7403 & 1.8981 & & \\
\hline SIZE & 19.227 & 19.633 & 19.673 & 19.368 & 19.209 & & \\
\hline BRAZIL & Low & 2 & 3 & 4 & High & H-L & \\
\hline Return & 0.0054 & 0.0082 & 0.0099 & 0.0148 & 0.0210 & 0.0156 & * \\
\hline BTM & 2.5073 & 1.9367 & 2.3631 & 2.7022 & 2.9007 & & \\
\hline SIZE & 20.969 & 21.231 & 20.922 & 20.415 & 19.782 & & \\
\hline CHILE & Low & 2 & 3 & 4 & High & H-L & \\
\hline Return & 0.0037 & 0.0063 & 0.0041 & 0.0066 & 0.0029 & -0.0007 & \\
\hline BTM & 0.8631 & 0.8429 & 0.8641 & 1.0456 & 1.8425 & & \\
\hline SIZE & 24.893 & 25.768 & 26.003 & 25.732 & 24.351 & & \\
\hline MEXICO & Low & 2 & 3 & 4 & High & H-L & \\
\hline Return & 0.0076 & 0.0069 & 0.0080 & 0.0039 & -0.0008 & -0.0084 & * \\
\hline BTM & 0.7857 & 0.8541 & 1.1494 & 1.5257 & 2.1425 & & \\
\hline SIZE & 22.403 & 22.870 & 22.099 & 21.679 & 20.695 & & \\
\hline \multicolumn{8}{|c|}{ Panel B: Size Portfolios } \\
\hline ARGENTINE & Small & 2 & 3 & 4 & Big & B-S & \\
\hline Return & 0.0059 & 0.0015 & 0.0022 & -0.0007 & 0.0039 & -0.0020 & \\
\hline BTM & 2.4436 & 1.9115 & 1.5532 & 1.0218 & 0.6744 & & \\
\hline BSM & 0.0515 & 0.0560 & 0.0622 & 0.0393 & 0.0279 & & \\
\hline BRAZIL & Small & 2 & 3 & 4 & Big & B-S & \\
\hline Return & 0.0158 & 0.0147 & 0.0116 & 0.0053 & 0.0095 & -0.0063 & \\
\hline BTM & 3.2572 & 2.0587 & 2.2859 & 1.7206 & 2.1085 & & \\
\hline BSM & 0.1519 & 0.1275 & 0.0892 & 0.0693 & 0.0379 & & \\
\hline CHILE & Small & 2 & 3 & 4 & Big & B-S & \\
\hline Return & 0.0000 & 0.0062 & 0.0072 & 0.0053 & 0.0049 & 0.0048 & \\
\hline BTM & 1.8567 & 1.1412 & 0.9599 & 0.8108 & 0.6746 & & \\
\hline BSM & 0.0710 & 0.0099 & 0.0045 & 0.0033 & 0.0025 & & \\
\hline MEXICO & Small & 2 & 3 & 4 & Big & B-S & \\
\hline Return & -0.0004 & 0.0058 & 0.0052 & 0.0055 & 0.0093 & 0.0097 & * \\
\hline BTM & 2.6394 & 1.2350 & 1.1519 & 0.8168 & 0.5537 & & \\
\hline $\mathrm{BSM}$ & 0.1026 & 0.0508 & 0.0438 & 0.0250 & 0.0043 & & \\
\hline
\end{tabular}


TABLE 3: Dependent sort by size and BSM and by BSM and Size

This table presents the January 1997 - January 2007 returns from the dependent sort by size and BSM default risk levels (Panel A) and by BSM default risk levels and size (Panel B). Size is sorted into tertiles for Chile and Mexico and for Argentine and Brazil, the median is used to categorize the stocks as small or big. BSM is sorted into tertiles for Chile and Mexico and for Argentine and Brazil, the median is used to categorize the stocks as low or high default risk. * and \# denote return differentials (H-L, High minus Low, and B-S, Big minus Small) that are significant at the $5 \%$ and $10 \%$ levels, respectively, using the Newey-West (1987) standard errors.

Panel A: Dependent sort by Size and BSM

\begin{tabular}{|c|c|c|c|c|c|}
\hline \multirow[t]{2}{*}{ ARGENTINE } & & \multicolumn{4}{|c|}{ BSM } \\
\hline & & LOW & 2 & HIGH & H-L \\
\hline \multirow{2}{*}{ SIZE } & SMALL & 0.0049 & -0.0006 & 0.0026 & -0.0022 \\
\hline & BIG & 0.0058 & 0.0018 & 0.0024 & -0.0034 \\
\hline \multirow[t]{2}{*}{$B R A Z I L$} & & \multicolumn{4}{|c|}{ BSM } \\
\hline & & LOW & 2 & HIGH & H-L \\
\hline \multirow{2}{*}{ SIZE } & SMALL & 0.0080 & 0.0136 & 0.0196 & 0.0116 * \\
\hline & BIG & 0.0012 & 0.0071 & 0.0122 & $0.0110 \quad \#$ \\
\hline \multirow[t]{3}{*}{ CHILE } & & \multicolumn{4}{|c|}{ BSM } \\
\hline & & LOW & 2 & HIGH & H-L \\
\hline & SMALL & 0.0047 & 0.0053 & 0.0017 & -0.0030 \\
\hline \multirow[t]{2}{*}{ SIZE } & 2 & 0.0079 & 0.0014 & 0.0059 & -0.0020 \\
\hline & BIG & 0.0055 & 0.0041 & 0.0057 & 0.0001 \\
\hline \multirow[t]{3}{*}{ MEXICO } & & \multicolumn{4}{|c|}{ BSM } \\
\hline & & LOW & 2 & HIGH & H-L \\
\hline & SMALL & 0.0046 & 0.0030 & -0.0030 & -0.0075 \\
\hline \multirow[t]{2}{*}{ SIZE } & 2 & 0.0089 & 0.0101 & -0.0003 & $-0.0091 *$ \\
\hline & BIG & 0.0084 & 0.0078 & 0.0066 & -0.0017 \\
\hline
\end{tabular}

Panel B: Dependent sort by BSM and Size

\begin{tabular}{|c|c|c|c|c|c|}
\hline \multirow[t]{2}{*}{ ARGENTINE } & & \multicolumn{4}{|c|}{ SIZE } \\
\hline & & SMALL & 2 & BIG & B-S \\
\hline \multirow{2}{*}{ BSM } & LOW & 0.0083 & -0.0024 & 0.0029 & -0.0053 \\
\hline & HIGH & 0.0023 & 0.0045 & 0.0002 & -0.0021 \\
\hline \multirow[t]{2}{*}{ BRAZIL } & & \multicolumn{4}{|c|}{ SIZE } \\
\hline & & SMALL & 2 & BIG & B-S \\
\hline \multirow{2}{*}{ BSM } & LOW & 0.0116 & 0.0080 & 0.0048 & -0.0068 \\
\hline & HIGH & 0.0181 & 0.0209 & 0.0148 & -0.0033 \\
\hline \multirow[t]{3}{*}{ CHILE } & & \multicolumn{4}{|c|}{ SIZE } \\
\hline & & SMALL & 2 & BIG & B-S \\
\hline & LOW & 0.0044 & 0.0073 & 0.0045 & 0.0001 \\
\hline \multirow[t]{2}{*}{ BSM } & 2 & 0.0054 & 0.0060 & 0.0046 & -0.0008 \\
\hline & HIGH & 0.0007 & 0.0076 & 0.0024 & 0.0017 \\
\hline \multirow[t]{3}{*}{ MEXICO } & & \multicolumn{4}{|c|}{ SIZE } \\
\hline & & SMALL & 2 & BIG & B-S \\
\hline & LOW & 0.0059 & 0.0100 & 0.0064 & 0.0004 \\
\hline \multirow[t]{2}{*}{ BSM } & 2 & 0.0069 & 0.0051 & 0.0073 & 0.0004 \\
\hline & HIGH & 0.0028 & -0.0021 & 0.0038 & 0.0010 \\
\hline
\end{tabular}


TABLE 4: Return and Characteristics of BTM Portfolios

This table presents the average return, Size and BSM characteristics of the BTM portfolios in each of the markets considered for the period January 1997 - January 2007. * and \# denote return differentials (H-L, High minus Low) that are significant at the 5\% and $10 \%$ levels, respectively, using the Newey-West (1987) standard errors.

\begin{tabular}{crrrrrl}
\hline ARGENTINE & Low & $\mathbf{2}$ & $\mathbf{3}$ & $\mathbf{4}$ & High & H-L \\
\hline Return & -0.0036 & 0.0003 & -0.0030 & 0.0130 & 0.0082 & 0.0119 \# \\
Size & 20.972 & 20.258 & 19.340 & 18.471 & 17.701 & \\
BSM & 0.0274 & 0.0280 & 0.0430 & 0.0534 & 0.0849 & \\
\hline $\boldsymbol{B R A Z I L}$ & Low & $\mathbf{2}$ & $\mathbf{3}$ & $\mathbf{4}$ & High & H-L \\
\hline Return & -0.0030 & 0.0087 & 0.0003 & 0.0119 & 0.0214 & $0.0244^{*}$ \\
Size & 21.416 & 21.308 & 20.222 & 20.344 & 19.769 & \\
BSM & 0.0382 & 0.0593 & 0.1070 & 0.0952 & 0.1377 & \\
\hline $\boldsymbol{C H I L E}$ & Low & $\mathbf{2}$ & $\mathbf{3}$ & $\mathbf{4}$ & High & H-L \\
\hline Return & -0.0034 & 0.0069 & 0.0022 & 0.0073 & 0.0119 & \multirow{2}{*}{$0.0153 *$} \\
Size & 25.981 & 25.930 & 25.472 & 25.162 & 24.187 & \\
BSM & 0.0051 & 0.0064 & 0.0143 & 0.0160 & 0.0485 & \\
\hline $\boldsymbol{M E X I C O}$ & Low & $\mathbf{2}$ & $\mathbf{3}$ & $\mathbf{4}$ & High & H-L \\
\hline Return & 0.0007 & 0.0042 & 0.0026 & 0.0073 & 0.0098 & $0.0091 *$ \\
Size & 23.342 & 22.734 & 21.987 & 21.291 & 20.236 & \\
BSM & 0.0261 & 0.0242 & 0.0297 & 0.0465 & 0.1052 & \\
\hline
\end{tabular}


TABLE 5: Dependent sort by BTM and BSM and by BSM and BTM

This table presents the January 1997 - January 2007 returns from the dependent sort by BTM and BSM default risk levels (Panel A) and by BSM default risk levels and BTM (Panel B). BTM is sorted into tertiles for Chile and Mexico and for Argentine and Brazil, the median is used to categorize the stocks as low or high book to market. BSM is sorted into tertiles for Chile and Mexico and for Argentine and Brazil, the median is used to categorize the stocks as low or high default risk. * and \# denote return differentials (H-L, High minus Low) that are significant at the $5 \%$ and $10 \%$ levels, respectively, using the Newey-West (1987) standard errors.

\begin{tabular}{|c|c|c|c|c|c|}
\hline \multicolumn{6}{|c|}{ Panel A: Dependent sort by BTM and BSM } \\
\hline \multirow[t]{2}{*}{ ARGENTINE } & & \multicolumn{4}{|c|}{ BSM } \\
\hline & & LOW & 2 & HIGH & H-L \\
\hline \multirow{2}{*}{ BTM } & LOW & 0.0035 & -0.0002 & -0.0064 & -0.0099 \\
\hline & HIGH & 0.0141 & 0.0053 & 0.0084 & -0.0057 \\
\hline \multirow[t]{2}{*}{ BRAZIL } & & \multicolumn{4}{|c|}{ BSM } \\
\hline & & LOW & 2 & HIGH & H-L \\
\hline \multirow{2}{*}{ BTM } & LOW & -0.0002 & 0.0058 & 0.0039 & 0.0042 \\
\hline & HIGH & 0.0160 & 0.0106 & 0.0250 & 0.0090 \\
\hline \multirow[t]{3}{*}{ CHILE } & & \multicolumn{4}{|c|}{ BSM } \\
\hline & & LOW & 2 & HIGH & H-L \\
\hline & LOW & 0.0004 & 0.0033 & -0.0007 & -0.0011 \\
\hline \multirow[t]{2}{*}{ BTM } & 2 & 0.0043 & 0.0063 & 0.0001 & -0.0042 \\
\hline & HIGH & 0.0093 & 0.0117 & 0.0105 & 0.0012 \\
\hline \multirow[t]{3}{*}{ MEXICO } & & \multicolumn{4}{|c|}{ BSM } \\
\hline & & LOW & 2 & HIGH & H-L \\
\hline & LOW & 0.0048 & 0.0018 & -0.0023 & $-0.0071 \neq$ \\
\hline \multirow[t]{2}{*}{ BTM } & 2 & 0.0090 & 0.0039 & -0.0009 & $-0.0099 *$ \\
\hline & HIGH & 0.0159 & 0.0055 & 0.0055 & $-0.0104 \neq$ \\
\hline \multicolumn{6}{|c|}{ Panel B: Dependent sort by BSM and BTM } \\
\hline \multirow[t]{2}{*}{ ARGENTINE } & & \multicolumn{4}{|c|}{ BTM } \\
\hline & & LOW & 2 & HIGH & H-L \\
\hline \multirow{2}{*}{ BSM } & LOW & -0.0006 & 0.0009 & 0.0092 & $0.0098 \neq$ \\
\hline & HIGH & -0.0077 & 0.0040 & 0.0083 & $0.0160 \nRightarrow$ \\
\hline \multirow[t]{2}{*}{ BRAZIL } & & \multicolumn{4}{|c|}{ BTM } \\
\hline & & LOW & 2 & HIGH & H-L \\
\hline \multirow{2}{*}{ BSM } & LOW & -0.0033 & 0.0058 & 0.0122 & $0.0155 \nRightarrow$ \\
\hline & HIGH & 0.0079 & -0.0028 & 0.0352 & $0.0273 *$ \\
\hline \multirow[t]{3}{*}{ CHILE } & & \multicolumn{4}{|c|}{ BTM } \\
\hline & & LOW & 2 & HIGH & H-L \\
\hline & LOW & -0.0008 & 0.0068 & 0.0097 & 0.0105 \\
\hline \multirow[t]{2}{*}{ BSM } & 2 & -0.0004 & 0.0055 & 0.0114 & 0.0119 \\
\hline & HIGH & -0.0013 & 0.0027 & 0.0104 & 0.0116 \\
\hline \multirow[t]{3}{*}{ MEXICO } & & \multicolumn{4}{|c|}{ BTM } \\
\hline & & LOW & 2 & HIGH & H-L \\
\hline & LOW & 0.0011 & 0.0105 & 0.0110 & 0.0099 \\
\hline \multirow[t]{2}{*}{ BSM } & 2 & 0.0026 & 0.0063 & 0.0107 & 0.0081 \\
\hline & HIGH & -0.0044 & 0.0042 & 0.0033 & 0.0077 \\
\hline
\end{tabular}


TABLE 6: Dependent sort by size and BTM

This table presents the January 1997 - January 2007 returns from the dependent sort by size and BTM. Size is sorted into tertiles for Chile and Mexico and for Argentine and Brazil, the median is used to categorize the stocks as small or big. * and \# denote return differentials (H-L, High minus Low) that are significant at the $5 \%$ and $10 \%$ levels, respectively, using the Newey-West (1987) standard errors.

\begin{tabular}{|c|c|c|c|c|c|}
\hline \multirow[t]{2}{*}{ ARGENTINE } & & \multicolumn{4}{|c|}{ BTM } \\
\hline & & LOW & 2 & HIGH & H-L \\
\hline \multirow{2}{*}{ SIZE } & SMALL & -0.0089 & 0.0076 & 0.0080 & 0.0169 \\
\hline & BIG & -0.0044 & 0.0026 & 0.0113 & 0.0157 \\
\hline \multirow[t]{2}{*}{ BRAZIL } & & \multicolumn{4}{|c|}{ BTM } \\
\hline & & LOW & 2 & HIGH & H-L \\
\hline \multirow{2}{*}{ SIZE } & SMALL & 0.0061 & 0.0131 & 0.0302 & 0.0241 \\
\hline & BIG & -0.0067 & 0.0113 & 0.0027 & 0.0094 \\
\hline \multirow[t]{3}{*}{ CHILE } & & \multicolumn{4}{|c|}{ BTM } \\
\hline & & LOW & 2 & HIGH & H-L \\
\hline & SMALL & -0.0033 & 0.0035 & 0.0116 & 0.0149 \\
\hline \multirow[t]{2}{*}{ SIZE } & 2 & 0.0004 & 0.0065 & 0.0103 & 0.0099 \\
\hline & BIG & 0.0024 & 0.0036 & 0.0089 & 0.0065 \\
\hline \multirow[t]{3}{*}{ MEXICO } & & \multicolumn{4}{|c|}{ BTM } \\
\hline & & LOW & 2 & HIGH & H-L \\
\hline & SMALL & -0.0094 & 0.0033 & 0.0096 & 0.0190 \\
\hline \multirow[t]{2}{*}{ SIZE } & 2 & 0.0025 & 0.0036 & 0.0115 & 0.0090 \\
\hline & BIG & 0.0050 & 0.0101 & 0.0072 & 0.0022 \\
\hline
\end{tabular}


TABLE 7: Fama - MacBeth Regressions

The Fama-Macbeth regression tests are performed on individual equity returns. The regressions relate individual stock returns to their past month's size, BTM, and BSM (DLI) characteristics and the products of the respective variables, which aim to capture the interaction effects of each pair of variables. * and \# denote coefficients that are significant at the $5 \%$ and $10 \%$ levels, respectively.

$$
\begin{aligned}
& R_{i, t}=\alpha+\beta . \text { Size }_{t-1}+u_{i, t} \\
& R_{i, t}=\alpha+\beta \cdot B T M_{t-1}+u_{i, t} \\
& R_{i, t}=\alpha+\beta . D L I_{t-1}+u_{i, t} \\
& R_{i, t}=\alpha+\beta . \text { Size }_{t-1}+\gamma \cdot \text { BTM }_{t-1}+\lambda \cdot D L I_{t-1}+u_{i, t} \\
& R_{i, t}=\alpha+\beta \cdot \text { Size }_{t-1}+\gamma \cdot \text { BTM }_{t-1}+\lambda \cdot D L I_{t-1}+\delta_{1} \cdot D L I_{t-1} \cdot \text { Size }_{t-1}+\delta_{2} \cdot D L I_{t-1} \cdot B T M_{t-1}+u_{i, t}
\end{aligned}
$$

\begin{tabular}{|c|c|c|c|c|c|c|c|c|c|}
\hline & Constant & & SIZE & & BTM & & DLI & SIZE*DLI & BTM*DLI \\
\hline \multirow[t]{5}{*}{ ARGENTINE } & 0.030896 & & -0.001408 & & & & & & \\
\hline & -0.005532 & & & & 0.004378 & * & & & \\
\hline & 0.003386 & & & & & & -0.030316 & & \\
\hline & -0.042648 & & 0.001778 & & 0.006951 & * & -0.056917 & & \\
\hline & -0.033991 & & 0.001357 & & 0.007182 & * & -0.348463 & 0.03588 & -0.319926 \\
\hline \multirow[t]{5}{*}{$B R A Z I L$} & 0.059408 & * & -0.002304 & \# & & & & & \\
\hline & -0.004822 & & & & 0.00552 & * & & & \\
\hline & 0.008542 & & & & & & 0.038245 & $*$ & \\
\hline & 0.052895 & & -0.002678 & \# & 0.005161 & $*$ & -0.021316 & & \\
\hline & 0.017296 & & -0.001214 & & 0.007541 & * & 0.010377 & 0.001622 & -0.016891 \\
\hline \multirow[t]{5}{*}{ CHILE } & -0.011588 & & 0.000696 & & & & & & \\
\hline & 0.00217 & & & & 0.004394 & \# & & & \\
\hline & 0.005878 & & & & & & 0.011599 & & \\
\hline & -0.039228 & \# & 0.001572 & \# & 0.006405 & * & -0.037765 & \# & \\
\hline & -0.049609 & * & 0.001875 & $*$ & 0.008152 & * & 3.657642 & -0.112487 & -1.010344 \\
\hline \multirow[t]{5}{*}{ MEXICO } & -0.035811 & \# & 0.001822 & $*$ & & & & & \\
\hline & 0.000109 & & & & 0.002496 & \# & & & \\
\hline & 0.004206 & & & & & & -0.028278 & & \\
\hline & -0.083745 & * & 0.003739 & * & 0.005122 & * & -0.043741 & & \\
\hline & -0.096208 & * & 0.004329 & * & 0.00704 & $*$ & 3.710639 & -0.159662 & -0.397914 \\
\hline
\end{tabular}

